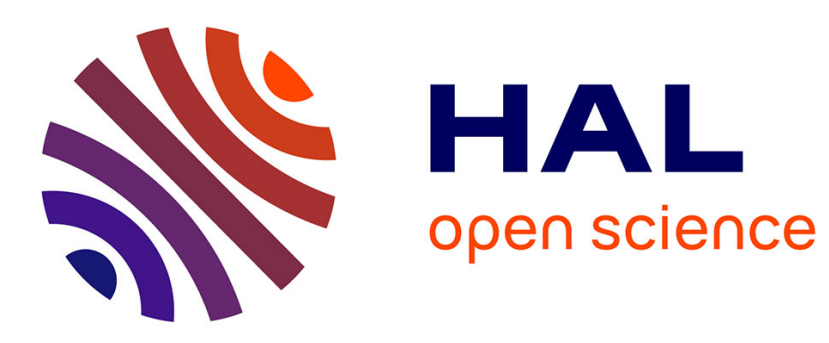

\title{
A Practical Scheme for Induction Motor Speed Sensorless Field Oriented Control
}

Abdessalam Makouf, Mohamed Benbouzid, Demba Diallo, Noureddine Bouguechal

\section{- To cite this version:}

Abdessalam Makouf, Mohamed Benbouzid, Demba Diallo, Noureddine Bouguechal. A Practical Scheme for Induction Motor Speed Sensorless Field Oriented Control. IEEE Transactions on Energy Conversion, 2004, 19 (1), pp.230-231. hal-01052446

\section{HAL Id: hal-01052446 https://hal.science/hal-01052446}

Submitted on 26 Jul 2014

HAL is a multi-disciplinary open access archive for the deposit and dissemination of scientific research documents, whether they are published or not. The documents may come from teaching and research institutions in France or abroad, or from public or private research centers.
L'archive ouverte pluridisciplinaire HAL, est destinée au dépôt et à la diffusion de documents scientifiques de niveau recherche, publiés ou non, émanant des établissements d'enseignement et de recherche français ou étrangers, des laboratoires publics ou privés. 


\title{
A Practical Scheme for Induction Motor Speed Sensorless Field Oriented Control
}

\author{
A. Makouf ${ }^{1,2}$, M.E.H. Benbouzid ${ }^{1}$, Senior Member, IEEE, D. Diallo ${ }^{1}$, Member, IEEE and N.E. Bouguechal ${ }^{2}$ \\ ${ }^{1}$ Centre de Robotique d'Electrotechnique et d'Automatique, University of Picardie "Jules Verne" \\ 7, Rue du Moulin Neuf, 80000 Amiens, France \\ Phone: +33 322827680 -Fax: + 33322827822 -E-mail: m.benbouzid@ieee.org \\ ${ }^{2}$ University of Batna, Algeria
}

\begin{abstract}
This paper deals with a practical scheme of induction motor drive speed sensorless control. It requires the presence of an adaptive flux observer. The speed estimator is based on the induction motor magnetic characteristic slope approximation to the mutual inductance value. Encouraging simulation results have been obtained.
\end{abstract}

\section{NOMENCLATURE}

$V, I(i), \varphi=$ voltage, current, flux;

$\omega(\Omega) \quad=$ rotor speed;

$R, L, M=$ resistance; inductance, mutual inductance;

$T_{r} \quad=$ rotor time constant, $T_{r}=L_{r} / R_{r}$;

$\sigma \quad=$ total leakage coefficient, $\sigma=1-M^{2} / L_{s} L_{r} ;$

$\gamma \quad=$ constant, $\gamma=-\left(R_{s}+M^{2} R_{r} / L_{r}{ }^{2}\right) / \sigma L_{s}$;

$K=$ constant, $K=M / \sigma L_{s} L_{r}$;

$\bar{x}(\hat{x})=$ complex (estimated) value.

\section{INTRODUCTION}

Induction motor drive researches have been concentrated in the elimination of speed sensor at the motor shaft without deteriorating the dynamic performance of the drive control system. Different schemes for speed sensorless in field orientation have been proposed in the past few years. A state of the art of the sensorless control of ac drive is given in [1].

This paper presents a practical solution to estimate the induction motor speed in the rotor flux oriented control system frame taking into account rotor resistance variations. In fact, vector control strategy is very sensitive to flux estimation mainly altered by motor parameter variations. It was then imperative to identify them [2-3]. Moreover, fast flux estimation and parameter identification achieve high dynamic performance and speed accuracy. Such features have been considered in the proposed control scheme [4-5].

\section{THE INDUCTION MOTOR MODEL}

An induction motor model can be described in a stator reference frame with the following equation.

$\left[\begin{array}{l}\frac{d \bar{i}_{s}}{d t} \\ \frac{d \bar{\varphi}_{r}}{d t}\end{array}\right]=\left[\begin{array}{cc}\gamma & \frac{K}{T_{r}}-j \omega K \\ \frac{M}{T_{r}} & -\frac{1}{T_{r}}+j \omega\end{array}\right]\left[\begin{array}{c}\bar{i}_{s} \\ \bar{\varphi}_{r}\end{array}\right]+\left[\begin{array}{l}1 \\ 0\end{array}\right] \frac{\bar{V}_{s}}{\sigma L_{s}}$

The rotor flux orientation is achieved by the following transformation from $\alpha-\beta$ to $d-q$ frame. $\left[\begin{array}{l}x_{d} \\ x_{q}\end{array}\right]=\frac{1}{\sqrt{\varphi_{r \alpha}^{2}+\varphi_{r \beta}^{2}}}\left[\begin{array}{cc}\varphi_{r \alpha} & \varphi_{r \beta} \\ -\varphi_{r \beta} & \varphi_{r \alpha}\end{array}\right]\left[\begin{array}{l}x_{\alpha} \\ x_{\beta}\end{array}\right]$

This transformation leads to

$\left\{\begin{array}{l}\varphi_{r d}=\sqrt{\varphi_{r \alpha}^{2}+\varphi_{r \beta}^{2}} \\ \varphi_{r q}=0\end{array}\right.$

Figure 1 shows the general structure in which flux and torque are respectively controlled by the currents $i_{s d}$ and $i_{s q}$ in the synchronous rotating frame fixed with flux.

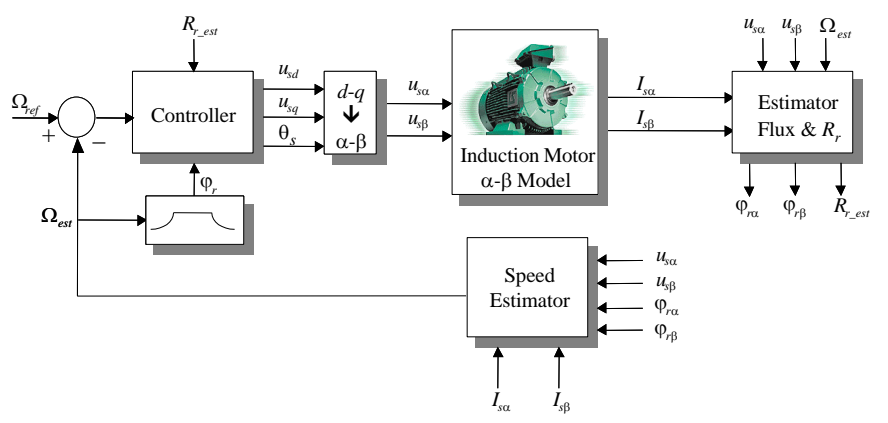

Fig. 1. Induction motor control structure.

\section{THE SPEED ESTIMATOR}

If we choose the motor speed $\omega$ as an intermediate variable, equation (1) could be written as

$\left\{\begin{array}{l}\frac{d \bar{i}_{s}}{d \omega} \frac{d \omega}{d t}=\gamma \bar{i}_{s}+\left(\frac{1}{T_{r}}-j \omega\right) K \bar{\varphi}_{r}+\frac{\bar{V}_{s}}{\sigma L_{s}} \\ \frac{d \bar{\varphi}_{r}}{d \omega} \frac{d \omega}{d t}=\frac{M}{T_{r}} \bar{i}_{s}-\left(\frac{1}{T_{r}}-j \omega\right) \bar{\varphi}_{r}\end{array}\right.$

From the above, the following equation is then obtained

$\left(\frac{d \bar{\varphi}_{r}}{d \bar{i}_{s}}\right)\left(\gamma \bar{i}_{s}+\left(\frac{1}{T_{r}}-j \omega\right) K \bar{\varphi}_{r}+\frac{\bar{V}_{s}}{\sigma L_{s}}\right)=\frac{M}{T_{r}} \bar{i}_{s}-\left(\frac{1}{T_{r}}-j \omega\right) \bar{\varphi}_{r}$

Where $d \bar{\varphi}_{r} / d \bar{i}_{s}$ represents the slope value for each point of the induction motor magnetic characteristic.

$\bar{\varphi}_{r}=L_{r} \bar{i}_{r}+M \bar{i}_{s}$ 
The magnetic saturation is neglected on the basis of a physical consideration. In fact, the induction motor temperature increase (thermal effect), due to its operation, will perturb and slow down the magnetic saturation process [5]. This has led us to consider $M$ as a constant. In this case

$$
\frac{d \bar{\varphi}_{r}}{d \bar{i}_{s}}=L_{r} \frac{d \bar{i}_{r}}{d \bar{i}_{s}}+M
$$

This equation can be written as

$$
\frac{d \bar{\varphi}_{r}}{d \bar{i}_{s}}=K_{s a t}
$$

Where $K_{\text {sat }}$ represents the magnetic characteristic slope that changes with the motor load. In fact, the first part of (7) may be written as

$$
L_{r} \frac{d \bar{i}_{r}}{d \bar{i}_{s}}=L_{r}\left(\frac{d \bar{i}_{s}}{d t}\right)^{-2}\left(\frac{d \bar{i}_{r}}{d t} \bullet \frac{d \bar{i}_{s}}{d t}+j\left(\frac{d \bar{i}_{r}}{d t} \times \frac{d \bar{i}_{s}}{d t}\right)\right)
$$

In this case, it is numerically checked that (9) real part absolute value increases and does not exceed the mutual inductance value in loaded conditions. Furthermore, we have noticed that the imaginary part remains slight. Therefore, the two following statements are derived: $K_{\text {sat }}=M$ for unloaded motor operation; and $K_{\text {sat }} \# 0$ for rated load motor operation.

With the above considerations and in the particular case of small and medium power induction motor, the following approximation could be written

$$
K_{s a t} \approx M
$$

From (10) and (5), the motor speed estimator is extracted.

$$
\hat{\omega}=\frac{1}{\left(K+\frac{1}{M}\right)} \frac{1}{\hat{\varphi}_{r}{ }^{2}}\left[\left(\gamma-\frac{1}{T_{r}}\right)\left(\bar{i}_{s} \times \hat{\bar{\varphi}}_{r}\right)+\frac{1}{\sigma L_{s}}\left(\bar{V}_{s} \times \hat{\bar{\varphi}}_{r}\right)\right]
$$

As it is shown by (11), the speed estimator is composed of two terms. The first one has the drawback of being sensitive to rotor and stator resistance that may vary owing to temperature. However, at motor rated load operation, we have

$$
\frac{1}{\left(K+\frac{1}{M}\right)} \frac{1}{\varphi_{r}^{2}}<<1
$$

Therefore, the parameter variation influence is attenuated.

\section{SIMULATION RESULTS}

The proposed speed estimator has been simulated on a 4$\mathrm{kW}$ induction motor (Fig. 1).

For simulation purposes, the transient behavior of the speed estimator is evaluated during $3 \mathrm{sec}$. At $1 \mathrm{sec}$, a $15 \mathrm{Nm}$ load torque is applied and removed at $2 \mathrm{sec}$. In these conditions, Fig. $2 \mathrm{a}$ shows that good performances are achieved and demonstrates the speed estimator robustness against parameter variations. Moreover, a change in the speed reference at $2.5 \mathrm{sec}$ is well tracked. Figures $2 \mathrm{~b}$ and $2 \mathrm{c}$ demonstrate the speed estimator capability for different induction motor operation conditions particularly those at low speed.

To illustrate the speed estimator robustness, computer simulations have been carried out in the case of an induction motor fed by a PWM-VSI inverter. Figure $2 \mathrm{~d}$ clearly shows the robustness of the proposed speed estimator when a $15 \mathrm{Nm}$ load torque is applied at $1 \mathrm{sec}$ and removed at $2 \mathrm{sec}$ and when the speed reference is change at $2.5 \mathrm{sec}$.

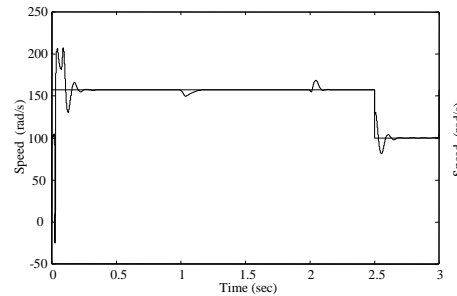

(a) With $200 \%$ increase of $R_{r}$.

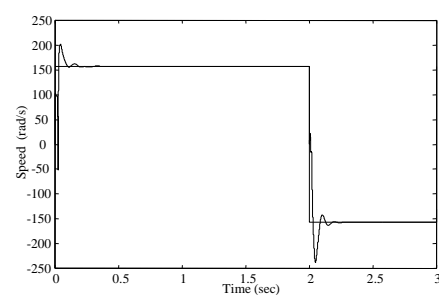

(c) With $20 \mathrm{Nm}$ of load torque.

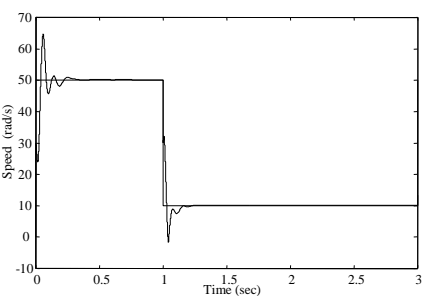

(b) With $20 \mathrm{Nm}$ of load torque.

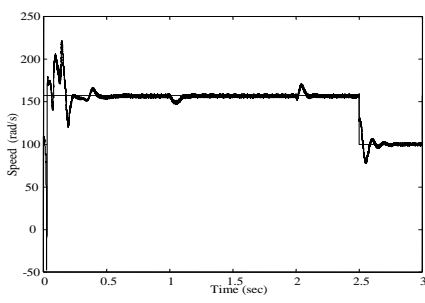

(d) PWM-VSI inverter.
Fig. 2. Speed estimation.

\section{CONCLUSION}

This paper dealt with a practical speed estimator for induction motor sensorless control. It requires the presence of an adaptive flux observer. The speed estimator is based on the induction motor magnetic characteristic slope approximation to the mutual inductance value. Computer simulations show the feasibility and the robustness of the proposed speed estimator.

\section{REFERENCES}

[1] J. Holtz, "Methods for speed sensorless control of AC drives", in Sensorless Control of AC Motor Drives, IEEE Press Book, 1996.

[2] J. Maes et al., "Speed-sensorless direct torque control of induction motors using an adaptive flux observer," IEEE. Trans. Industry Applications, vol. 36, $\mathrm{n}^{\circ} 3$, May-June 2000, pp. 778-785.

[3] K. Akatsu et al., "Online rotor resistance estimation using the transient state under the speed sensorless control of induction motor," IEEE Trans. Power Electronics, vol. 15, n³, May 2000, pp 553-560.

[4] M.E.H. Benbouzid et al., "Induction motors direct field oriented control with robust on-line tuning of rotor resistance," IEEE Trans Energy Conversion, vol. 14, n 4, December 1999, pp 1038-1042.

[5] T. Noguchi et al., "Field-orientated control of an induction motor with robust on-line tuning of its parameters," IEEE Trans. Industry Applications, vol. 33, n 1 , January-February 1997, pp 35-42. 